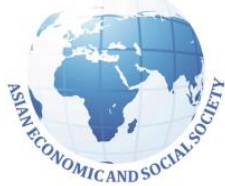

AESS

\section{Asian Journal of Empirical Research}

http://aessweb.com/journal-detail.php?id=5004 DOI: $10.18488 /$ journal.1007/2016.6.6/1007.6.142.151

\title{
APPRAISAL OF AFRICA TRADITIONAL MEDIA (ORAMEDIA) AS COMMUNICATION TOOLS FOR EFFECTIVE MANAGEMENT OF ELECTORAL VIOLENCE IN NIGERIA
}

\author{
Odigbo, Ben E. \\ Department of Marketing, University of Calabar, Nigeria \\ Silk Ugwu Ogbu \\ Centre for Distance \& E-Learning, University of Nigeria, Nsukka \\ Okonkwo, Raphael Valentine \\ Department of Marketing, Michael Okpara University of Agriculture, Umudike-Umuahia, Nigeria
}

\section{Article History:}

Received: 6 June 2016

Revised received: 12 August

2016

Accepted: 23 August 2016

Online available: 5 Sep 2016

\section{Keywords:}

Electoral Violence,

Africa traditional media,

crisis management,

political marketing \& public relations

\begin{abstract}
The study dwelt on an appraisal of the potency of Africa traditional media vehicles (oramedia) as communication tools for effective prevention and management of pre- and post-electoral violence in Nigeria. It was occasioned by the perennial incidence of electoral violence that has characterized general elections in the country since independence. The specific objectives were to: determine the effect of oramedia human-vehicular media as antidote to electoral violence in Nigeria; examine the effect of oramedia traditional anti-violence symbols as tools for preventing electoral violence in Nigeria; and determine the effect of oramedia idiomatic expressions as tools for preventing electoral violence in Nigeria. The study adopted survey design, where primary data were sourced through structured questionnaire. The study area was Portharcourt in the South-South, Kaduna in the North, Aba in the South-East and Lagos in the South-West. The results show that: Oramedia human-vehicular media; oramedia traditional anti-violence symbols and oramedia idiomatic expressions were significantly effective antidote for the prevention and management of electoral violence in Nigeria. Based on these outcomes, it was then recommended that the Nigerian Government and the Independent National Electoral Commission (INEC), should give priority and devote more resources to the use of Africa traditional media for checkmating pre- and post-electoral violence in the country.
\end{abstract}

\section{INTRODUCTION}

Nigeria had at sundry times witnessed electoral crises and dysfunctional conflicts in almost all the elections conducted in the country since independence. In almost all the elections conducted in the country, there is none that did not witness the loss of hundreds of lives through electoral violence.

Corresponding author's

Name: Odigbo, Ben E.

Email address: bodigbo@yahoo.com 
Sometimes, religious, ethnic or tribal sentiments have been fingered for directly or indirectly being behind the crises. Politicians are often accused of negatively harvesting from these factors to advance their selfish political interests (Bekoe, 2011; Odigbo et al., 2014). For instance, Citizens for Nigeria (2009) accused some political elites in some parts of Nigeria for exploiting the Boko Haram crisis at one time or the other for cheap political gains. Again, Allafrica.com (2009) observed that the Jos crises of 2013 also erupted during an electioneering campaign tour of Jos by a prominent Nigerian politician, who allegedly asked Muslims not to vote for Christians. Thus, the Cleen Organization (2009) asserts that the ethnic mobilization of support by politicians in Nigeria during electioneering campaigns is one major factor that whips up public sentiments for violence and crisis during electioneering in the country.

In almost all elections conducted in the country, hundreds of lives were lost. For instance, during the politically-motivated Jos crisis of 2010 over 650 innocent people, mainly hapless women and children lost their lives. Again, during the 2011 general elections, considered one of the freest/fairest but most violent in the country, electioneering violence was again unleashed on the masses, where over 850 lost their lives in Kaduna State alone (Bekoe, 2011; Crisis Group, 2014) due to the unethical political communications and win-at-all-costs attitude of some Nigerian politicians. In the 2007, 2011 and 2014 elections, terrorism dimensions were also added to the litany of electoral violence in Nigeria political history, through bombings and news of bombings here and there (Amadi, 2011; Njoku, 2011; Osai, 2010).

According to Diamond (1998), some Nigerian politicians employ ethnic sentiments, allegations and accusations to exploit the masses ignorance and turn them against one another, for selfish electoral victories for themselves. Hence, Okadigbo (1987) lamented that the lack of value-concensus and cultural homogeneity are the cause of incessant conflicts between ethnic groups in the country pre-, during and post-elections. Hence, the study was informed by the need to appraise the implications of ethical political marketing communications on elections in Nigeria.

Odigbo (2016) believes that de-emphasizing the employment of mass media and laying of emphasis more on African traditional media (oramedia) as a political marketing and public relations communications' tool will provide a better antidote for curbing electoral violence in Nigeria, basing his argument on the grounds that the Agenda-setting theory does not work significantly in developing countries where majority of the citizens live in rural areas, and do not have access to mass media. Political Marketing and Public Relations has to do with the applications of marketing and public relations concepts, principles, techniques and strategies in the political sphere (Eze et al., 2016). Again, Osho (2011) observes that African traditional media (oramedia) tools are particularly more effective channel of communication amongst the Africa populace because of their uniqueness in the modern age which includes the widespread of usage amongst the people, its better appeal, deep effect and easy assimilation by the people. More still, the oramedia is more culture-centered and more long-lasting. It is a less expensive media and uses indigenous technology in disseminating information to the people, hence, communal in nature. Thus, the people believe in messages from it more than those from the conventional media.

After the 2007 general elections in Nigeria, majority of the citizens lost hope in electoral democracy due to the incessant massive rigging of votes that thwarted the citizens' right in electing candidates of their choices into positions of leadership in previous elections. It then took the late President Yar'Adua and President Goodluck Jonathan a good dose of sermon before they could convince Nigerians that future elections would be free and fair in the country. They kept faith with that promise, as the 2011 general elections were adjudged by both local and international monitors of being largely free and fair. However, the contest for power in Nigeria is still becoming bloodier and bloodier by the day. Innocent youth corpers working in some parts of the country were massacred in cold blood, hundreds of other citizens also lost their lives, churches, mosques, cars, houses and other valuable property were burnt, all in the name of election. 
Thus, the political firmament of the country to most observers was still cast in gloomy clouds, even as some of the candidates shifted their battle grounds to the election petition tribunals. The Boko Haram bombings here and there which many believed to have some political undertone were yet another headache. People are still being kidnapped in the country daily, spurning fears and social insecurity everywhere. Unemployment is still alarmingly high and yet prices of essential commodities like electricity tariff, kerosene, etc. are being raised beyond the reach of the common man. Certainly, this is not what the masses voted for.

To the pessimists, the whole thing could be just a disaster waiting to happen. But to the die-hard optimists, the country could still get it right if the present anti-corruption crusade is pursued conscientiously and devoid of political with-hunting. The present government, they argue, needs to be given some time. But another school of thought believes that it is the politicians and political parties in Nigeria that neglect the suffering masses and therefore set up the spiraling social crises in the country. This is because most of them employ unethical communications in shopping for vote/voters' during elections. A school of thought believes that the employment of more of Africa traditional media as political marketing communications tool in the Nigerian electoral system will be an antidote for enthroning peaceful elections in the country. Finding out to what extent these arguments hold some water was the main focus of the study.

These were the issues that motivated this study to critically appraise the effectiveness of African traditional media as communications' tool for preventing pre- and post-election violence in Nigeria. The specific objectives were to:

i. Determine the effect of oramedia human-vehicular media as antidote to electoral violence in Nigeria;

ii. Examine the effect of oramedia traditional anti-violence symbols as tools for preventing electoral violence in Nigeria; and,

iii. Determine the effect of oramedia idiomatic expressions as tools for preventing electoral violence in Nigeria.

The study was, however, restricted in scope to a survey of the opinion of respondents selected from four states in four geographical areas of Nigeria, namely Enugu in the South-East, Lagos in the South-West, Port Harcourt in the South-South and Kano in the North. The respondents were politicians, party leaders, voters and some workers of the electoral body. All those are the key stakeholders in the country's political system.

\section{LITERATURE REVIEW}

\subsection{The concept of political marketing/public relations}

Political Marketing and Public Relations has to do with the applications of marketing and public relations concepts, principles, techniques and strategies in the planning, packaging and implementation of political and electioneering projects. It is therefore a useful tool for political education, mass mobilization for participation in the electoral process and public enlightenment for good conduct during elections (Eze et al., 2016). Lee-Marshment (2001) observes that political marketing is a good philosophy in political engineering, While Black (1989) asserts that political public relations ensures effective two-way communication between the electorates and politicians based on truth and adequate information. Such, no doubt, has the capacity to serve as a good antidote to electioneering conflict/crisis in multi-ethnic and multi-religious societies like Nigeria.

However, in doing this, Lee-Marshment (2001) categorized the electioneering marketing behaviour of political parties into three:

- Those that adopt the product concept: by forcing their thoughts, beliefs and actions down the throats of the electorates (customers), whether they like it or not. 
- Sales-oriented political parties: that try to sell their beliefs, arguments or manifestoes to the public through heavy adverts, inducements and campaigns, and abandon them as soon as voted into office, and

- Market-oriented political parties that not only design their manifestoes to suit voters' satisfaction, but also deliver on their promises, political offerings/dividends to the voters, when voted into office.

It is only after good works based on good intentions, not ill - motives, that wholesome democracy rooted in peace and socioeconomic development will be enthroned in any country, through sound political marketing and public relations campaigns. If political parties therefore adopt market oriented approach in elections, there will be fewer frictions in the country, because they would tailor all their actions to suit electorates (society's) needs, wants and satisfaction.

On the other hand, effective two-way communication will help to douse rumors, build mutual understanding and usher in peaceful elections in any system Black (1989). Wikipedia (2010) tells us that some media of two-way communication for political campaigns include: street campaigns, house-to-house campaigns, radio phone-in programs, television phone-in programs, website contacts, suggestion boxes, public complaints boxes, chatrooms, instant messaging, socialnetworking, telephone conversations, and other face-to-face media like workshops, seminars, symposia, interviews, etc. that offer opportunities for questions-and-answers sessions to the electorates.

Kotler (2003) posits that political candidates, political parties and their policies are products that could be sold to the electorates (consumers) and other operators in the political market. But to do this effectively, they must employ the right political marketing and political public relations strategies. Samaila (2003) defined political marketing as the application of marketing principles, techniques, marketing system, methods or strategies for the realization of political goals. The marketing of party programmes, in most cases, bears close resemblance to the marketing of physical products.

Nkamnebe (2003) supports this view that under the perspective of political marketing, the same process of product (idea) development akin to tangible product development has been recognized. As is consistent with marketing orthodoxy, managers of the political process can increase the satisfaction level in the polity by recognizing that enduring political behaviour could be achieved by systematically conceptualizing political ideas to meet the needs and wants of political consumers, Nkamnebe (2003) adds.

Meanwhile, Galadima (2003) observes that the issue of corruption and violence in the Nigeria political space has attracted much attention now because of the recurrent sectionally and politically induced civil crises which started since the beginning of democratic experiment and general elections in Nigeria. Obasanjo (2002) had attributed violence in Nigeria's body politic to lack of the culture of debate and argument over issues when there are disagreements between politicians, and the resort to tribal and sectional sentiments rather than political party machineries for the resolution of problems.

Galadima (2003) catalogued other causes of electioneering violence in Nigeria to include:

$>$ Alleged marginalization of some sections of the country,

$>$ Widespread electoral frauds or riggings in the political system,

$>$ Unilateral cancellation or alternation of already agreed political arrangements without recourse to other parties involved,

$>$ Influence peddling and struggle to control groups, sections and persons and resistance by opponents within political constituents.

$>$ Incessant feuds between Godfathers and Godsons due to selfish pecuniary interests.

Anifowose (1982) asserts that: "collective violence has flowed regularly from the Nigerian political process... Men seeking to seize, hold, or realign the levers of power have continually engaged in 
collective violence as part of their struggle." Political violence in the Nigerian context had included riots as in the Western part of the country in 1966 and again over the June 12 protests in 1983, party clashes, violent demonstrations, looting, arson and political assassinations (Ugwuanyi \& Odigbo, 2012).

Considering the high level of violence that follows every election in Nigeria, Adedeji (2001) doubts if the country is really democratic yet. Odigbo (2003) observed that blind ethnic and tribal cleavages, uncontrolled corruption in high places, politically motivated assassinations, election riggings and long court cases are issues that distort the Nigerian democratic system. While high decrees of poverty, unemployment and hunger are the triggers behind the social crisis. But that could be avoided through a wholesome political marketing culture rooted in market-orientation and ethical public relations practices, some experts assert.

\subsection{African traditional media (oramedia) as political education tool}

The indigenous people of Africa have been using their traditional media (oramedia) as means of communication amongst themselves since time immemorial. The oramedia employs both human and non-human vehicles like talking drums, the folk songs, drama, festivals, town criers, traditional wears, the artifacts, art works, paintings, stories, and among others cultural architecture that reflects in the palaces, shrines, and African cities, towns and villages (Odigbo et al., 2013; Ugboaja, 1985; Osho, 2011). It also involves the use of idiomatic expressions, traditional symbols and folklores in communicating deep meanings to the people. Oramedia is therefore a veritable means of communication by the people, especially in rural settings. Oramedia organs like masquerades, palm fronds (omunkwu), local white chalks (NZU), kolanuts are employed in dispute resolutions in Igboland (Odigbo et al., 2013). For instance, masquerades are used to settle disputes when they put palm fronds or draw a white chalk over a disputing property. This communicates that the place is now sacred and must not be trespassed by any of the disputing parties, until the case is fully settled (Odigbo et al., 2013). The high content of non-verbal components in oramedia actually makes them to be more effective because non-verbal communicates the mind more than verbal, especially during conflict resolutions (Osho, 2011). This must have informed the appraisal of oramedia for checkmating the incessant cases of electoral violence in Nigeria, in this study.

\subsection{Political marketing and communication}

Political Marketing and Public Relations (PMPR) is the application of marketing principles and public relations strategies to win acceptability and support of a political party, politicians, political course, programme or policy. Samaila (2003) says that specifically, it is the use of marketing techniques in politics to influence the voting (buying) decision of the electorate (customers). LeeMarshment (2001) says that political marketing borrows from the core marketing concepts of product, sales and market-orientation, and techniques such as market intelligence, and adapts them to suit traditional tenets of political science to produce an integrated theoretical framework. Nwosu (2003) says that a basic secret of success in any public relations, image building or promotional activity is to do before telling people that you have done, or to perform first before telling the world that you have performed. So, political parties and politicians must do much before political campaigns (the promotional activities aimed at making them win public acceptance or votes). That is to say your past track records in life counts in your acceptability for public office.

In the observation of Harrop (2008), political marketing offers us the opportunity to understanding electoral change and the interface with marketing principles and techniques. Farrell (2006) observed that elections are the fulcrum of the relationship between political parties and the electorates. Considering the fact that elections in Nigeria since the first republic have been marred by violence, blood sheds, massive riggings, court cases etc. what is the place of Africa traditional media (oramedia) as political marketing and public relations communications tool for engendering peaceful elections in the country? Finding answers to this poser was the major thrust of the study. 


\section{METHODOLOGY}

For our methodology, opinion survey techniques was employed in gathering primary data for this study, while the data so gathered were analyzed in percentage frequencies. It is an empirical situation analysis study (SAS). A sample size of 333 was determined from the population by using Taro Yamani's statistical model, at 5\% margin of error and 95\% level of confidence. The following nullhypotheses were formulated and tested the in the study:

Ho1: Determine the effect of oramedia human-vehicular media as antidote to electoral violence in Nigeria.

Ho2: Examine the effect of oramedia traditional anti-violence symbols as tools for preventing electoral violence in Nigeria.

Ho3: Determine the effect of oramedia idiomatic expressions as tools for preventing electoral violence in Nigeria.

\section{DATA PRESENTATION AND ANALYSIS}

\subsection{Respondents' demographic data}

The respondents' demographic data show that: $200(60.06 \%)$ were males while $133(39.94 \%)$ were females; $75(22.52 \%)$ were in the age bracket of 21 to 30 years; $100(30.03 \%)$ in the age range of 31 to 40 years, another $100(30.03 \%)$ were aged between 41 to 50 years, while the remaining 58 $(17.42 \%)$ were either 50 years or above. For their educational qualifications, 100 respondents or $30.03 \%$ had only O'Levels; 75 respondents or $22.52 \%$ had either OND or NCE, 100 respondents or $30.03 \%$ had First Degrees, while the remaining 58 respondents or $17.42 \%$ had either Masters Degrees or PhDs. Their marital status indicates that 205 respondents or $61.56 \%$ were married, while the remaining 128 or $(38.44 \%)$ were still single as at the time of this survey.

Table 1: Assessment of oramedia human-vehicular media as antidote to electoral violence in Nigeria

\begin{tabular}{lcc}
\hline Options & Frequency & Percentage \\
\hline True & 286 & $86 \%$ \\
False & 20 & $6 \%$ \\
Uncertain & 37 & $8 \%$ \\
Total & 333 & $100 \%$ \\
\hline
\end{tabular}

Source: Field survey, 2015

$86 \%$ of the respondents affirmed that oramedia human-vehicular media would serve as antidote to electoral violence in Nigeria if employed in political education of the electorates and politicians, $6 \%$ disagreed with this view, while $8 \%$ could not make up their minds on this. Figure 1 gives a graphical picture of this result.

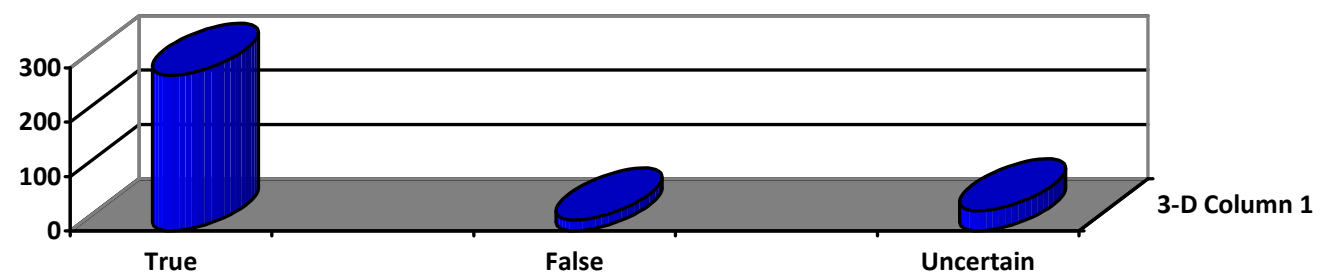

Figure 1: Assessment of oramedia human-vehicular media as antidote to electoral violence in Nigeria 
Table 2: Assessment of the effect of oramedia traditional anti-violence symbols as tools for preventing electoral violence in Nigeria

\begin{tabular}{lcc}
\hline Options & Frequency & Percentage \\
\hline Agree & 280 & $84 \%$ \\
Disagree & 23 & $7 \%$ \\
Uncertain & 30 & $9 \%$ \\
Total & 333 & $100 \%$ \\
\hline
\end{tabular}

Source: Field survey, 2015

Data displayed on table 2 indicates that $280(84 \%)$ of the respondents agreed that oramedia traditional anti-violence symbols will be significantly effective as tools for preventing electoral violence in Nigeria. $23(7 \%)$ of the respondents disagreed with that; while $30(9 \%)$ of the respondents were not certain. Figure 2 gives a pictorial view of this result.

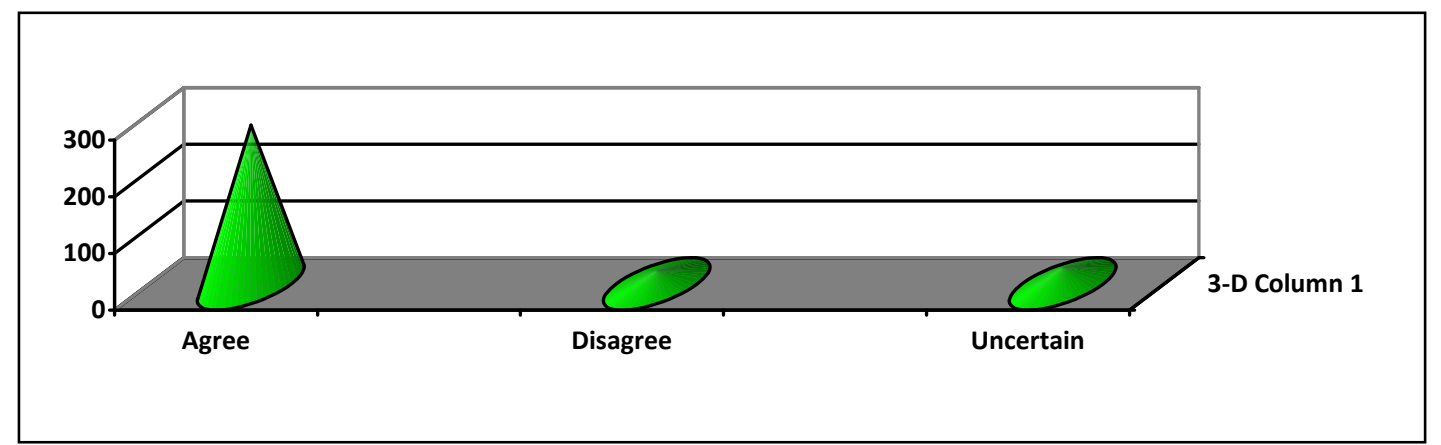

Figure 2: Effect of oramedia traditional anti-violence symbols as tools for preventing electoral violence in Nigeria

Table 3: Assessment of effectiveness of oramedia idiomatic expressions as tools for preventing electoral violence in Nigeria

\begin{tabular}{lcc}
\hline Options & Frequency & Percentage \\
\hline Agree & 260 & $78 \%$ \\
Disagree & 43 & $13 \%$ \\
Uncertain & 30 & $9 \%$ \\
Total & 333 & $100 \%$ \\
\hline
\end{tabular}

Source: Field Survey, 2015

Data on table 3 shows that 260 (78\%) strongly believed that oramedia idiomatic expressions would serve as tools for effectively preventing electoral violence in Nigeria. $43(13 \%)$ of the respondents said they don't share the belief; while the remaining 30 (9\%) could not quite make up their minds on this. See figure 3 for a graphical representation of this result.

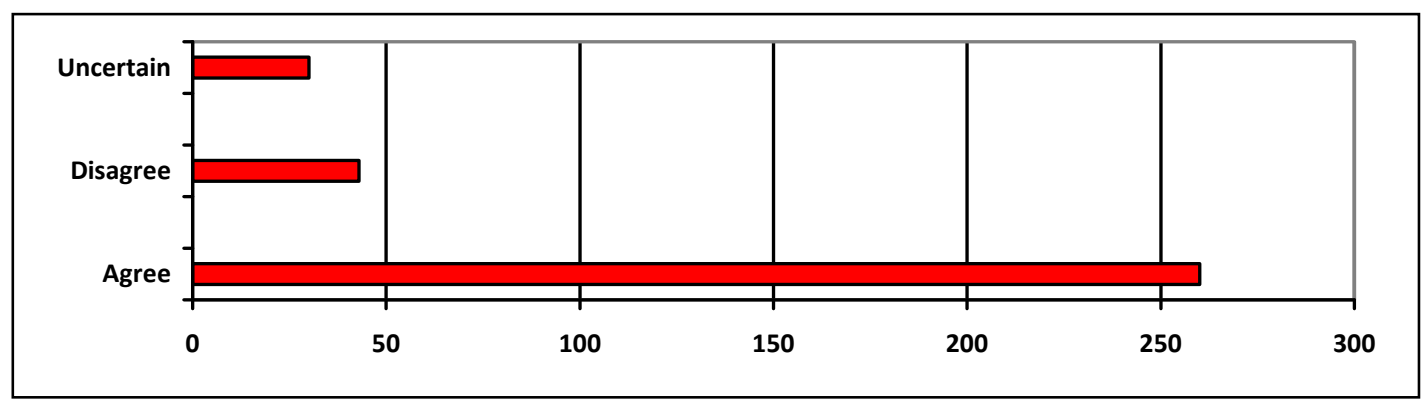

Figure 3: Effect of oramedia idiomatic expressions as tools for preventing electoral violence in Nigeria 


\section{SUMMARY OF RESULTS}

From the analysis of data, the following results were obtained:

i. Majority of the citizens $(86 \%)$ affirmed that oramedia human-vehicular media would serve as antidote to electoral violence in Nigeria if employed in political education of the electorates and politicians.

ii. Majority of the citizens (84\%) also believed that oramedia traditional anti-violence symbols will be significantly effective as tools for preventing electoral violence in Nigeria.

iii. Again, $78 \%$ who were in the majority also strongly believed that oramedia idiomatic expressions would serve as tools for effectively preventing electoral violence in Nigeria.

\section{DISCUSSION}

From the number 1 result of this study, which shows that majority of Nigerians (86\%) believed that oramedia human-vehicular media would serve as antidote to electoral violence in the country, if employed in political education of the electorates and politicians, the efficacy of African traditional media is therefore, no more in doubt. This result agrees with the standpoint of Osho (2011) who insists that the potency of oramedia over the orthodox/conventional media lies the fact that it is culturally based and natural with the tradition and customs of the people. It involves their language, dialect, individual occupation or family occupation or communal occupation. Most Africans live in the rural communities, raising livestocks or engaging in farming, notwithstanding that Africa has many big cities that are growing rapidly, like Lagos, Nigeria (with population of 18 Million); Abuja, the new Federal Capital Territory of Nigeria; Cairo, Egypt (with population of 15 Million); Casablanca, Morocco; and Cape Town, South Africa (Osho, 2011).

The number 2 result which indicates that majority of the citizens (84\%) also believed that oramedia traditional anti-violence symbols will be significantly effective as tools for preventing electoral violence in Nigeria is also a big eye-opener on the over-riding effectiveness and powers of the African traditional media. This will be particularly good in communicating deep meanings about the dangers of violence to the youths of the country, who are often recruited by unscrupulous politicians as their foot-soldiers to forment trouble during elections in the country, as observed by Iroegbu (2003). The result also agrees with the findings of Odigbo et al. (2013), that Africa traditional media could also be used for effective alternative disputes' resolution (ADR) tools in post-election matters, rather than the over-stuffing of our law courts with election petitions after every election season in the country.

Again, the number three result which reveals that $78 \%$ of Nigerians strongly believed that oramedia idiomatic expressions would serve as tools for effectively preventing electoral violence in Nigeria cannot be over-emphasized, because communicating in proverbs and idioms is still a huge way of life of the indigenous African people. These results attest to why the agenda-setting theory often do not work in Africa and other developing countries as postulated by Odigbo (2016).

\section{RECOMMENDATIONS}

Following the findings of this study, the researchers recommend that:

i. African traditional media (oramedia) human-vehicular media should be used more for the political education of Nigerian politicians, political parties, youths and the entire electorates to adopt violence-free electoral attitude through the electoral process; pre-, during and postelection periods.

ii. Oramedia traditional anti-violence symbols should also be employed in appealing to the minds the electorates, politicians and political parties in Nigeria on the dangers of electoral violence on individuals, families and society at large. 
iii. The Independent National Electoral Commission (INEC), politicians and political parties should be charged to inscribe such oramedia traditional anti-violence symbols in all their election materials, campaign materials, manifestoes, voting papers, etc.

iv. Nigerian politicians must be made to understand that they are in power or coming into power to protect the lives of the masses and not to 'feast' on them through electoral violence, to serve their selfish interests.

v. Finally, for peace to reign in Nigerian elections and democracy, politicians and political parties must imbibe ethical public relations practices by shunning the engagement of youths for political gangsterism, thuggery, ballot-box snatching and forceful manipulation of election results.

\begin{tabular}{|l|}
\hline Funding: This study received no specific financial support. \\
\hline Competing Interests: The authors declare that they have no conflict of interests. \\
\hline Contributors/Acknowledgement: All authors participated equally in designing and estimation of current \\
research. \\
\hline Views and opinions expressed in this study are the views and opinions of the authors, Asian Journal of \\
Empirical Research shall not be responsible or answerable for any loss, damage or liability etc. caused in \\
relation to/arising out of the use of the content.
\end{tabular}

\section{References}

Adedeji, A. (2001). Not yet uhuru for Nigeria. Newswatch Magazine, Lagos. March 12.

Allafrica.com (2009). Nigeria: How jos crisis erupted. www.allafrica.com/stories/200903240549.html.

Amadi, S. (2011). Stop this bombing in Nigeria. Daily Independent, February 24, pp. 5.

Anifowose, R. (1982). Violence and politics in Nigeria: the TIV and Yoruba experience. Enugu: Nok Publishers Ltd.

Bekoe, D. (2011). Nigeria's 2011 elections: Best run, but most violent. Peace Brief 103, United States Institute of Peace • www.usip.org, August 15, 2011. Retrieved 08 April 2013.

Black, S. (1989). Introduction to Public Relations, London: Modino Press Ltd. p.13.

Citizens for Nigeria (2009). Yar'Adua plans to exploit boko haram crisis. www.citizensforNigeria.com/index.php?option

Cleen.org report (2009). Ethnic mobilization during electioneering campaigns in Nigeria. www.cleen.org/citizenship and Identity crisis in Nigeria.

Crisis, G. (2014). Curbing violence in Nigeria (II): The boko haram insurgency. http://www.crisisgroup.org/media/files/Africa/west-africa/Nigeria/216-curbing-violence-innigeria-iithe-boko-hararam-insurgency.pdf.

Diamond, L. (1988). Class, ethnicity and democracy in Nigeria. Ibadan: Macmillan Press.

Eze, F. J., Odigbo, B. E., \& Ehikwe, A. E. (2016). Ethical political marketing and public relations (PMPR) communications for checkmating electoral violence in Nigeria. IOSR Journal of Business and Management, 18(4), 1-10.

Galadima, J. D. (2003). Mass media, corruption and violence in the Nigerian political system. POLIMEDIA: Media and politics in Nigeria, Enugu: ACCE and prime targets publishers.

Harrop, M. (2008). Political marketing. http:paoxforedjournals.org cgi/pdf-extrcat.

Iroegbu, P. (2003). Electoral fraud and Nigeria's democratic quest. http://nigeriaworld.com/articles/may/121.html.

Kotler, P. (2003). Marketing management: Analysis, planning, implementation and control, New Jersey: Prentice Hall Inc.

Lee-Marshment, J. (2001). Marriages of politics and marketing. Journal of Political Marketing, University of Aberdeen: Political Studies Association.

Njoku, C. (2011). Who fuels religious crisis in the North. Daily Nation, February 22, pp. 5.

Nkamnebe, A. D. (2003). The nature and characteristics of political marketing. Enugu: Polimedia: Media and Politics in Nigeria, ACCE and Prime Targets.

Nwosu, I. I. (2003). Role of the mass media in preventing political violence in Nigeria. Enugu: Polimedia: Media and Politics in Nigeria, ACCE and Prime Targets, p.2. 
Obasanjo, O. (2002). Steps to avoid violence in Nigerian polities. Report Submitted to the House of Representative.

Odigbo, B. (2003). Role of Public Relations and the Mass Media in Building and Sustaining Democracy in Nigeria. Enugu: Prime target publishers.

Odigbo, B. E., Anuforo, R., \& Odigbo, A. R. (2013) Curbing social inequalities and gender-based injustices in Igboland: The role of public relations. IOSR Journal of Business and Management, 10(4), 29-40.

Odigbo, B. E., Ogbu, S. U., \& Odigbo, A. R. (2014). The correlation between social violence and the comments of Nigerian politicians during electioneering campaigns: A political marketing study. Journal of Law, Policy and Globalization, 26, 1-12.

Odigbo, B. (2016). Social public relations (SPR) for enhanced immunization campaigns. Germany: Lambert Academic Publishers, p.156.

Okadigbo, C. (1987). Power and leadership in Nigeria. Enugu: Fourth Dimension Publishers.

Osai, J. (2010). Governors meet on crisis in Nigeria. Tribune, February 16, pp. 11.

Osho, S. A. (2011). The uniqueness of African means of communication in a contemporary world. http://www.africanoutlookonline.com/index.php? Retrieved 11/04/2013.

Samaila, M. (2003). Political Marketing in Nigerial POLIMEDI: Media and Politics in Nigeria. Enugu: ACCE and prime Targets Ltd.

Ugboaja, F. O. (1985). Oramedia in Africa. in: Communications in Africa, London: Hans Zell Publishers, p.5.

Ugwuanyi, U., \& Odigbo, B. (2012). Public relations strategies for managing religious, ethnic and social conflicts for the promotion of foreign direct investment (FDI) and development in Nigeria. European Journal of Business and Management, 4(17), 40-52.

Wikipedia (2010). Two-Way communications. At: http://www.wikipedia-two-waycommunications.html. 